\title{
INVESTIGATION OF RISK FACTORS IN CRYPTOGENIC ISCHEMIC STROKE
}

\author{
Yıldız ARSLAN*, Burcu SELBEST DEMIRTAŞ**, Cenk EKMEKCi***, Ufuk ŞENER* \\ *Izmir Tepecik Training and Research Hospital, Neurology Clinic, İzmir, TURKEY \\ **Denizli State Hospital, Neurology Clinic, Denizli, TURKEY \\ ***Izmir Tepecik Training and Research Hospital, Cardiology Clinic, İzmir, TURKEY
}

\begin{abstract}
INTRODUCTION: Cryptogenic ischemic stroke (CS) includes 30-40\% of all ischemic strokes. Several studies using different methods of prolonged cardiac monitoring determined atrial fibrillation (AF) in $12-25 \%$ of CS patients, however these findings are not enough to explain the etiology of most of the CSs. Our aim is to research thromboembolic sources and vascular risk factors in CS patients.

METHODS: The study enrolled 125 patients older than 45 years, 65 of them with CS according to Trial of Org 10172 in Acute Stroke Treatment (TOAST) criteria. Control group included patients admitted cardiology outpatient clinic with symptoms of nonspecific chest pain or dyspnea without cerebrovascular diseases. Patients with any history of AF or paroxysmal AF, intra-cardiac thrombus or valvular heart disease and left ventricular dysfunction, heart failure were excluded. Cardiovascular risk factors, left atrium diameter, left ventricle ejection fraction (EF) (\%) and 24-hour Holter ECG monitoring were examined. Blood total cholesterol, LDL, HDL, urea, creatine levels were also analyzed and compared.

RESULTS: Hypertension, diabetes mellitus, coronary artery diseases were more prevalent in the study group ( $\mathrm{p}<0.05$ ). LDL, total cholesterol and blood urea levels were significantly higher and HDL was lower in the study group ( $<<0.05$ ). There was no significant difference between two groups in terms of Holter ECG results. In the study group, six patients had non-sustained AF episodes ( $<30 \mathrm{sec}$.) and two had paroxysmal AF episodes. In control group only two patients had frequent $\mathrm{AF}$ episodes continuing $>30 \mathrm{sec}$.

DISCUSSION and CONCLUSION: Cardiovascular risk factors leading thromboembolism were prominently higher in CS patients, long-term ECG monitoring may explain only the cardioembolic sources due to arrhythmia. Investigation of thromboembolic sources is vital for determining the etiology of CS.
\end{abstract}

Keywords: Cryptogenic stroke, holter ECG, cardiovascular risk factors, thromboembolism.

\section{KRIPTOJENIK İSKEMIK İNMEDE RISK FAKTÖRLERININN ARAȘTIRILMASI}

\section{ÖZET}

GİRIȘ ve AMAÇ: Kriptojenik iskemik inme (Ki) tüm iskemik inmelerin \%30-40'ını kapsamaktadır. Farklı çalıșmalarda değişik uzun süreli kardiak monitorizasyon metodları kullanılarak Kİ hastalarının \%15-25'inde atrial fibrilasyon (AF) saptanmıştır, ancak bu bulgular Kİ etyolojisinin büyük bir kısmını açılamada yeterli değildir. Amacımız Kİ hastalarında tromboembolik kaynakların ve vasküler risk faktörlerinin araştırılmasıdır.

YÖNTEM ve GEREÇLER: Çalışmaya toplam 125 hasta dahil edildi, bunların 65 tanesi Trial of Org 10172 in Acute Stroke Treatment (TOAST) kriterlerine göre seçilmiş Kİ hastalarıydı. Kontrol grubuna kardioloji polikliniğine non spesifik göğüs ağrısı veya nefes darlığı ile başvuran ve serebrovasküler hastalığı olmayanlar dahil edildi. AF veya paroksismal AF öyküsü olanlar, intrakardiak trombus, kalp kapak hastalığı ve sol ventrikül disfonksiyonu veya kalp yetmezliği olan hastalar çalıșmadan dıșlandı. Kardiovasküler risk faktörleri, sol atrium çapı, sol ventrikül ejeksiyon fraksiyonu (EF)(\%) ve 24 saat holter EKG monitorizasyonu incelendi. Kan total kolesterol, LDL, HDL, üre, kreatin düzeyleri analiz edildi.

BULGULAR: Çalışma grubunda hipertansiyon, diyabet, koroner arter hastalığı anlamlı olarak yüksek saptandı $(\mathrm{p}<0.05)$. LDL, total kolesterol ve kan üre seviyeleri çalışma grubunda anlamlı yüksekti ve HDL seviyesi ise düşüktü ( $p<0.05)$. Holter EKG sonuçları açısından her iki grup arasında anlamlı fark saptanmadı. Çalışma grubunda, altı hastada sürekli olmayan AF epizodları (<30 sn.) ve iki hastada ise paroksismal AF epizodları vardı. Kontrol grubunda ise sadece iki hastada $>30 \mathrm{sn}$. süren sık AF epizodları mevcuttu.

\footnotetext{
Corresponding author: Ylldız Arslan MD. İzmir Tepecik Training and Research Hospital, Neurology Clinic, İzmir, Turkey.

Telephone: +902323443052 E-mail: dryildizarslan@yahoo.com

Received: 19.01.2019 Accepted: 15.03.2019

This article should be cited as following: Arslan Y, Selbest Demirtas B, Ekmekci C, Sener U. Investigation of risk factors in cryptogenic ischemic stroke.

Turkish Journal of Cerebrovascular Diseases 2019; 25 (1): 26-30. doi: 10.5505/tbdhd.2019.19480
} 
Arslan et al.

TARTIŞMA ve SONUÇ: Kİ populasyonunda tromboembolizme yol açan kardiovasküler risk faktörleri belirgin yüksek saptandı, uzun sureli EKG monitorizasyonu sadece aritmiye bağlı kardioembolik kaynakların nedenini açlklayabilir. Tromboembolik kaynakların araștırılması Kİ etiyolojisinin saptanmasında önemli yer tutmaktadır.

Anahtar Sözcükler: Kriptojenik inme, holter EKG, kardiovasküler risk faktörleri, tromboembolizm.

\section{INTRODUCTION}

Trial of Org 10172 in Acute Stroke Treatment (TOAST) classification, which is the one most commonly used in clinical practice, cryptogenic ischemic stroke (CS) is defined as brain infarction that is not attributable to a source of definite cardio-embolism, large artery atherosclerosis, or small artery disease despite a standard vascular, cardiac, and serologic evaluation. It accounts for $30-40 \%$ of ischemic strokes in recent stroke registries and databases $(1,2,3,3,4,5)$.

Occult atrial fibrillation (AF) is often suspected in cases of $\mathrm{CS}$, and determination of $\mathrm{AF}$ occurrence is considerable critical, because it changes preventive therapy from antiplatelet agents to a more effective prophylaxis with oral anticoagulation $(1,2,5,6) . \mathrm{AF}$ is a common cause of cardio-embolism, but it can be difficult to diagnose due to asymptomatic or paroxysmal episodes $(7,8,9,10)$. There is not a consensus among experts regarding the duration of cardiac monitoring and insufficient data to support the optimal costeffectivity $(5,10,11,12)$.

In clinical practice external 24-hour ECG recording (Holter) is frequently used, entailing the detection of previously undetermined $\mathrm{AF}$ in approximately $2 \%$ of stroke patients. Besides extending the ECG recording time from 24 to 72 hours increases the prevalence of paroxysmal $\mathrm{AF}$ after stroke from $1.2 \%$ to $6.1 \%(2,8)$. Even in selected high-risk patient group, the use of 24-h ECGs only improves new AF detection rates to just $10 \%$. According to the CHA2DS2-VASc score, the stroke linked to AF is related not only to the arrhythmia but also to several clinical characteristics and ranges from 1.3 to $15.2 \%$. Applying the higher rate of stroke to CS population, the final rate of ischemic events related to $\mathrm{AF}$ episodes should be no more than $2.43 \%$ (1). The other possible mechanisms are aortic atheromatous disease, or other cardiac sources such as patent foramen ovale (PFO), atrial or ventricular septal defect (ASD, VSD), undefined thrombophilia, subcritical cervicocerebral arterial steno-occlusive disease and other vasculopathies (13).

Turkish Journal of Cerebrovascular Diseases 2019; 25 (1): 26-30
In this study, we investigated and analyzed the vascular risk factors, thromboembolic sources and Holter ECG results between the control and CS patients. We also researched the etiological risk factors of CS according to TOAST criteria.

\section{MATERIAL AND METHODS}

\section{Study subjects}

This study enrolled 65 CS patients selected from 354 consecutive acute ischemic stroke patients with undetermined origin according to TOAST criteria between January 2015 and March 2016, retrospectively. Control group $(n=60)$ was selected consecutively from the patients admitted to cardiology outpatient clinic with the symptoms of nonspecific chest pain and dyspnea and without any valve pathologies, heart failure, arrhythmia, coroner artery disease and cerebrovascular diseases.

All patients were older than 45 years. This study was approved by the local ethic committee of education and research hospital (19.01.2016/decision no: 13) and written consents were taken from all subjects.

\section{TOAST criteria}

CS is a diagnosis of exclusion based upon a through investigation for potential stroke etiologies. The diagnosis of CS is made when a standard evaluation reveals no probable cause; there is no definite evidence of cardio-embolism, large artery atherosclerosis, small artery disease, or other determined etiology, and no evidence of $\mathrm{AF}$ on a 12-lead electrocardiogram (ECG) (13).

For the diagnosis of CS; brain imaging (cranial and diffusion MRI), CT or MR angiography, transthoracic echocardiography (TTE) and 24 hour Holter ECG were performed. Via TTE left ventricle ejection fraction (LVEF) and left atrium diameter (LAD) of all patients were measured. Holter ECG results were reviewed by a cardiologist.

Patients younger than 45 years, carotid artery stenosis $\geq \% 50$ demonstrated on BT or MR angiography, patients with any history of AF or paroxysmal AF, any other arrhythmia intra-cardiac 
thrombus or any other cause of cardiac embolism, valvular heart disease and left ventricular dysfunction, heart failure were excluded. In addition patients with aortic pathology, mechanical heart valve PFO, ASD or VSD revealed on TTE and hypercoagulable states, patients with primarily hemorrhagic stroke, or acute large vessel dissection and lacunar strokes were not included in the study group.

The patients of study group were included meeting the TOAST criteria as mentioned. Control group was selected from patients admitted to cardiology outpatient clinic who were taken 24 hour Holter ECG with symptoms of dyspnea or nonspecific chest pain and without cerebrovascular diseases and cardiac pathology.

Hypertension (HT), diabetes mellitus (DM), coronary artery diseases (CAD), chronic renal failure (CRF), LAD, Holter ECG results and LVEF were compared between groups. Routinely studied blood laboratory results; LDL, HDL, total cholesterol, triglycerides, hemoglobin, platelets, urea, creatine were also analyzed and compared.

\section{Holter ECG}

Three-channel NORAV DL 800 Holter ECG device was used to record 24 hour ECG results of patients. All records in NORAV DATABASE were analyzed by two independent observers (Holter ECG nurse and a cardiologist) separately. Finally the results were also examined and analyzed in detail by another cardiologist. Atrial fibrillation, atrial or ventricular ectopic activity, arrhythmias, tachycardia and other cardiac rhythm pathologies were noted.

\section{Laboratory tests}

Following a 8-hour fasting period, 5-ml venous blood was drawn from ante-cubital fossa for complete blood count and routine biochemical blood tests (glucose, urea, creatine, HDL, LDL, triglycerides, total cholesterol, $\mathrm{Ca}++, \mathrm{K}+, \mathrm{Cl}-$, liver enzymes, total and direct bilirubin, total protein, albumin) and also erythrocyte sedimentation rate (ESR), C-reactive protein were measured.

\section{Statistical analyses}

All data were analyzed using the Statistical Package for the Social Sciences, ver. 22.0, for Windows (SPSS; Chicago, IL). Numeric and categorical variables were compared with Chisquare and Student T-test between the groups. Pvalues $<0,05$ were accepted to indicate statistical significance.

\section{RESULTS}

In the study group, $96.9 \%(n=63)$ of patients had mRS: $0-2$ and only two (3.1\%) of them had mRS: 3 , further the mean value of NIHSS was $3,75 \pm 2,31$. Nineteen patients had multiple infarct areas and 46 patients had single infarct area. Most of them were in hemispheric and thalamic localization $(n=38)$, the second most was basal ganglia $(n=13)$ and the third was pons localized $(n=10)$. Only four of them had cerebellar infarct.

There was no difference between the groups in terms of age and gender. HT, DM, CAD were significantly prevalent in the study group (Table I).

Table I. Demographical parameters.

\begin{tabular}{llll}
\hline Parameters & $\begin{array}{l}\text { Study group } \\
\text { (n:65) }\end{array}$ & $\begin{array}{l}\text { Control group } \\
\text { (n:60) }\end{array}$ & P value \\
\hline Age & $60.5 \pm 11.4$ & $57.2 \pm 13.6$ & 0.150 \\
Female (\%) & $38.4 \%$ & $55 \%$ & 0.064 \\
HT (\%) & $63.1 \%$ & $40 \%$ & $\mathbf{0 . 0 1 0}$ \\
DM (\%) & $41.5 \%$ & $20 \%$ & $\mathbf{0 . 0 0 9}$ \\
CAD (\%) & $16.9 \%$ & $0 \%$ & $\mathbf{0 . 0 0 1}$ \\
CRF (\%) & $12.3 \%$ & $6.6 \%$ & 0.285 \\
\hline HT: hypertension, DM: diabetes mellitus, CAD: coronary artery diseases,
\end{tabular}
CRF: chronic renal failure.

LDL, total cholesterol and blood urea levels were significantly higher in the study group. HDL was higher in the control group. There was no difference in terms of other parameters (table II).

Table II. Biochemical blood parameters.

\begin{tabular}{llll}
\hline Parameters & $\begin{array}{l}\text { Study group } \\
\text { (n:65) }\end{array}$ & $\begin{array}{l}\text { Control group } \\
\text { (n:60) }\end{array}$ & P value \\
\hline Hemoglobin & $13.4 \pm 1.8$ & $13.2 \pm 1.1$ & 0.373 \\
LDL & $150.6 \pm 59.7$ & $118.3 \pm 33.8$ & $\mathbf{0 . 0 0 1}$ \\
HDL & $42.1 \pm 10.3$ & $48.7 \pm 11.1$ & $\mathbf{0 . 0 0 1}$ \\
Total cholesterol & $222.8 \pm 53$ & $197.5 \pm 45.6$ & $\mathbf{0 . 0 0 5}$ \\
Triglycerides & $192.0 \pm 142.4$ & $166.6 \pm 84.6$ & 0.223 \\
Platelet & $260.6 \pm 91.9$ & $271.2 \pm 116.4$ & 0.576 \\
Urea & $43.3 \pm 20.6$ & $32.3 \pm 12$ & $\mathbf{0 . 0 0 1}$ \\
Creatine & $1.39 \pm 1.9$ & $1.00 \pm 0.7$ & 0.122 \\
\hline
\end{tabular}

LDL: low-density lipoprotein HDL: high-density lipoprotein.

There was no difference between the results of Holter ECG and LAD. Additionally mean LVEF was significantly higher in the control group, but in normal ranges (Table III).

In the study group, six patients had nonsustained AF episodes ( $<30$ sec.) and two had paroxysmal AF episodes. In control group only two patients had frequent AF episodes continuing $>30$ sec. 
Table III. Cardiac parameters.

\begin{tabular}{llll}
\hline Parameters & $\begin{array}{l}\text { Study } \\
\text { group (n:65) }\end{array}$ & $\begin{array}{l}\text { Control } \\
\text { group (n:60) }\end{array}$ & $\begin{array}{l}\text { P } \\
\text { value }\end{array}$ \\
\hline AF episodes & $\begin{array}{l}\text { 2=sustained } \\
\text { 6=non } \\
\text { sustained }\end{array}$ & $\begin{array}{l}\text { 2=sustained } \\
\text { 0=non } \\
\text { sustained }\end{array}$ & \\
& 40 & 41 & 0.181 \\
AEA, VEA tachycardia & 17 & 17 & \\
NSR & $36.04 \pm 5.64$ & $34.56 \pm 5.23$ & 0.131 \\
Left atrium diameter & 59.26 \pm 2.89 & $60.26 \pm 2.59$ & $\mathbf{0 . 0 4 3}$ \\
Left ventricle EF (\%) & aEA: Atrial ectopic activity VEA: Ventricular ectopic activity NSR: normal \\
sinus rhythm EF: ejection fraction AF: atrial fibrillation. &
\end{tabular}

\section{DISCUSSION}

Most of the etiological factors of CS are unknown. In clinical practice Holter monitoring (HM) is frequently used to clarify these unknown factors, but external HM for 24 to 72 hours detected AF only in the range of 2,4\% - 6,0\% (11). Both the CRYSTAL AF and EMBRACE randomized multi-center large trials demonstrated the incremental diagnostic value of extended cardiac monitoring over contemporary practice (1). Obviously ideal timing and duration of monitoring techniques are unclear currently in clinical guidelines. The duration can be extended to 7-30 days as mentioned in literature $(8,14)$. A metaanalysis of 32 studies by Kishore et al found a diagnosis of $\mathrm{AF}$ in $11.5 \%$ in this population. Unfortunately, differences in enrollment criteria, follow-up duration, and end point definition make comparison between any of these studies difficult $(11,15)$.

Long duration of HM should be applied to the patients with elevated cardiac troponin I (cTnI) levels and multiple infarcts as demonstrated in literature $(6,16)$. Boire et al found that $\mathrm{AF}$ was more prevalent in patients with elevated cTnI levels than patients with normal cTnI levels using ECG and 24-hour HM (6). Additionally, it was asserted that multiple acute and chronic cerebral infarcts on CT and MRI were associated with paroxysmal AF (PAF) (16). However long-term ECG monitoring could not explain the diagnosis in approximately $90 \%$ of patients with CS. The importance of understanding these aspects resides in the fact that diagnostic route of CS should not be unbalanced only toward the research of AF (1).

We think that most of them may be due to thromboembolism or vascular risk factors predisposing endothelial damage and thrombus. In the present study we investigated the thromboembolic and cardiovascular risk factors that may explain most of the unknown causes in CS patients and compared with a control group.

In our study we determined only two $\mathrm{AF}$ episodes $>30 \mathrm{sec}$. in each group. Moreover in the study group six patients had AF episodes $<30$ sec. called in current literature as non sustained $\mathrm{AF}$ which is higher in CS patients as we demonstrated and indicated in the study of Arsava et al. It was asserted that these episodes may enhance the risk of ischemic stroke (17). However there is no difference between groups in terms of sustained or non-sustained AF.

In the analysis from EMBRACE, the largest $\mathrm{AF}$ detection trial in patients with CS, they found that the number of HM detected atrial ectopic activity (AEA) was a potent independent predictor of $\mathrm{AF}$ (12). The ratios of AEA or ventricular EA in control and study groups were similar in the present study. We cannot suggest that frequent AEA may be a stroke risk marker independent of causal mechanisms, such as the development of longlasting AF (7).

In this study, the patients with cardiovascular risk factors; HT, DM and CAD were significantly more prevalent in CS patients. Mean LVEF ratio was significantly lower in the study group, but in normal ranges. Another thromboembolic source; LAD was larger in the study group, but the difference was not statistically different.

Blood LDL, total cholesterol and urea levels were also significantly higher in the study group and HDL was lower. It was demonstrated in logistic regression models that we need larger study and control groups to verify these findings leading us to focus on the thromboembolic etiology of CS.

There were some limitations of our study. Firstly, the number of patients was small and the study design was retrospective. Secondly the duration of HM was not long enough to exclude arrhythmia. Lastly we did not analyze the cTnI levels in those patients.

In routine clinical practice, we suggested that it is hard to apply HM to all CS patients for 30 days. Even in longer HM studies most of the CS etiology still remains unknown. However, in TOAST classification we think that there is no detailed description of a pathway in patients with multiple potential etiological factors, so many patients remain in the cryptogenic stroke group. The extracranial or intracranial atherosclerosis causing < $50 \%$ luminal stenosis of the artery supplying the 
area of ischemia, large LAD and HT, DM, hypercholesterolemia may be the etiological causes of CS accounting for thromboembolism and cardio-embolism. Large randomized controlled studies are needed to clarify this issue.

As conclusion, cardiovascular risk factors leading thromboembolism, arterial thrombosis, cerebral small vessel disease may be substantially higher within CS population, long-term ECG monitoring may not explain the diagnosis in most of the patients with CS. Lastly we suggested that in the future, the definition and criteria of CS should be updated and reviewed according to new findings.

\section{REFERENCES}

1. Lilli A, Di Cori A.The cold facts of long-term ECG monitoring' Expert Rev. Cardiovasc. Ther. 2015;13(2): 125-127.

2. Elijovich L, Josephson SA, Fung GL, Smith WS. 'Intermittent Atrial Fibrillation May Account for a Large Proportion of Otherwise Cryptogenic Stroke: A Study of 30-Day Cardiac Event Monitors' Journal of Stroke and Cerebrovascular Diseases, 2009;18(3): 185-9.

3. Pinho J, Braga CG, Rocha S, Santos A.F., Gomes A, Cabreiro A et al. 'Atrial Ectopic Activity in Cryptogenic Ischemic Stroke and TIA: A Risk Factor for Recurrence' Journal of Stroke and Cerebrovascular Diseases, 2015; 24(2): 507-510.

4. Ritter MA, Kochhäuser S, Duning T, Reinke F, Pott C, Dechering DG, et al. 'Occult Atrial Fibrillation in Cryptogenic Stroke Detection by 7-Day Electrocardiogram Versus Implantable Cardiac Monitors' Stroke. 2013; 44(5):1449-1452.

5. Ustrell X, Pellisé A. 'Cardiac Workup of Ischemic Stroke' Current Cardiology Reviews 2010; 6(3): 175-183.

6. Beaulieu-Boire I,Leblanc N, Berger L, Boulanger JM. 'Troponin Elevation Predicts Atrial Fibrillation in Patients with Stroke or Transient Ischemic Attack' Journal of Stroke and Cerebrovascular Diseases, 2013; 22(7): 978-983.

7. Dion F, Saudeau D, Bonnaud I, Friocourt P, Bonneau A, Poret $\mathrm{P}$, et al. 'Unexpected low prevalence of atrial fibrillation in cryptogenic ischemic stroke: a prospective study' J Interv Card Electrophysiol 2010; 28(2):101-107.
8. Jabaudon D, Sztajzel J, Sievert K, Landis T, Sztajzel R. 'Usefulness of Ambulatory 7-Day ECG Monitoring for the Detection of Atrial Fibrillation and Flutter After Acute Stroke and Transient Ischemic Attack' Stroke 2004; 35(7): 1647-1651.

9. Thakkar S, Bagarhatta R. 'Detection of paroxysmal atrial fibrillation or flutter in patients with acute ischemic stroke or transient ischemic attack by Holter monitoring' indian heart journal 2014; 66(2): 188-192.

10. Grond M, Jauss M, Hamann G, Stark E, Veltkamp R, Nabavi D. et al. 'Improved Detection of Silent Atrial Fibrillation Using 72-Hour Holter ECG in Patients With Ischemic Stroke: A Prospective Multicenter Cohort Study' Stroke 2013; 44(12):3357-3364.

11. Choe WC, Passman RS, Brachmann J, Morillo CA, Sanna T, Bernstein RA. et al for the CRYSTAL AF Investigators 'A Comparison of Atrial Fibrillation Monitoring Strategies After Cryptogenic Stroke (from the Cryptogenic Stroke and Underlying AF Trial)' Am J Cardiol 2015;116(6):889-893.

12. Gladstone DJ, Dorian P, Spring M, Panzov V, Mamdani M, Healey JS. et al; for the EMBRACE Steering Committee and Investigators 'Atrial Premature Beats Predict Atrial Fibrillation in Cryptogenic Stroke Results From the EMBRACE Trial' Stroke 2015;46(4):936-941.

13. Adams H, Bendixen BH, Kappelle LJ, Biller J, Love BB, Gordon DL et al and the TOAST Investigators 'Classification of Subtype of Ischemic Stroke Definitions for Use in a Multicenter Clinical Trial' Stroke 1993; 24(1):35-41 .

14. Rizos T, Quilitzsch A, Busse O, Haeusler KG, Endres M, Heuschmann P. et al. 'Diagnostic Work-Up for Detection of Paroxysmal Atrial Fibrillation After Acute Ischemic Stroke Cross-Sectional Survey on German Stroke Units Stroke. 2015;46(6): 1693-1695.

15. Kishore A, Vail A, Majid A, Dawson J, Lees KR, Tyrrell PJ et al. 'Detection of atrial fibrillation after ischemic stroke or transient ischemic attack: a systematic review and metaanalysis.' Stroke 2014;45(2):520-526

16. Alhadramy O, Jeerakathil TJ, Majumdar SR, Najjar E, Choy J, Saqqur M. 'Prevalence and Predictors of Paroxysmal Atrial Fibrillation on Holter Monitor in Patients With Stroke or Transient Ischemic Attack' Stroke. 2010; 41(11):25962600.

17. Arsava EM, Bas DF, Atalar E, Has AC, Oguz KK, Topcuoglu MA. 'Ischemic Stroke Phenotype in Patients With Nonsustained Atrial Fibrillation'Stroke. 2015; 46(3):634640. 